\title{
Corporate Governance: Shareholder Rights And Firm Performance
}

Lal C. Chugh, University of Massachusetts, USA

Joseph W. Meador, Northeastern University, USA

Matthew W. Meador, University of Michigan, USA

\begin{abstract}
In the $21^{\text {st }}$ century, greater attention is being paid to the issue of shareholder rights and corporate governance in U.S. corporations by regulators, shareholders and the general public. A previous paper by the authors finds that the level of shareholder rights generally has not increased and may have declined amongst the $S \& P 500$ companies, despite the recent legislative and regulatory reforms. Evidence suggests that instead firms are searching for an optimum level of shareholder rights that balances the risks and rewards of greater shareholder rights. This study investigates the financial performance of firms with greater shareholder rights (GSR) and contrasts it with that of firms with lower shareholder rights (LSR). This paper finds that GSR firms may perform better on some financial criteria, in absolute terms, but when adjusted for volatility, LSR firms may perform better, contrary to the conventional wisdom.
\end{abstract}

Keywords: corporate governance, shareholder rights and financial performance

\section{INTRODUCTION}

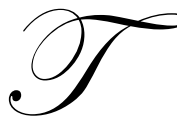

he importance of good corporate governance is well recognized amongst various constituents, including, investors, money managers, and regulatory and professional bodies. As a result, greater attention is being paid to developing processes for measuring, monitoring, and quantitatively assessing the corporate governance of U.S. publicly traded firms. This paper first discusses the standards for an ideal model of corporate governance, as described in the literature. Secondly, it reviews the academic research in this area and develops a theory of optimum shareholder rights. Thirdly, the study evaluates the financial and accounting performance of firms with varying degrees of shareholder rights. The methodology section describes the sample selection and data sources underlying the study. The results section describes the research findings, and the paper concludes with the summary and conclusion.

\section{CORPORATE GOVERNANCE IN THE U.S. PUBLIC CORPORATION - AN IDEAL}

The corporate governance ideal in the U.S. embodies the concept that the stockholders own the corporation (Bebchuk, 2006). As a result, they are entitled to share in the profits and future direction of the company through their voting rights. Shareholders elect the board of directors which is responsible for appointing senior management. Management becomes the agent of the stockholders and is charged with maximizing shareholder wealth. It is generally believed that greater shareholder rights are associated with better corporate governance and consequently greater efforts by management to enhance shareholder wealth. Thus, agency costs are reduced.

Shareholder-oriented corporate governance is generally assessed by four standards. The first standard describes the degree of board independence and performance. This standard embodies the notions that a substantial number of board members should be independent of the management, and the audit and compensation committees should be comprised of independent members, with financial expertise on the audit committee. Moreover, according to this standard, management decision processes should be transparent to the board for evaluation. 
The second standard prescribes equal voting rights for all shareholders without dual/multi- classes. Shareholder rights should not be abridged by takeover defenses, unequal voting rights, and restrictions on changing corporations' by-laws or limiting shareholder proposals. The shareholders should have the right to elect the full board each year, without the limitation of staggered terms. The shareholders should have the right to an independent nominating committee. Essentially, this second standard implies that the firm's management is not entrenched and can be replaced. Moreover, shareholders are free to sell the firm to outside parties.

The third standard of shareholder-oriented corporate governance emphasizes the importance of transparency of financial information and effectiveness of internal controls. Shareholders should have the right to select and change auditors periodically. This fourth and final standard ensures that there is an independent committee for determining management compensation, and that compensation is based on performance.

Recent legislation, such as the Sarbanes-Oxley Act of 2002 (SARBOX), and certain SEC and NYSE regulations, have addressed these four standards, mandating new practices such as required certification of financial statements by the CEO and CFO, disclosure of off balance sheet transactions, board review of financial controls, regular board meetings without the presence of management, required shareholder approval of all equity-based compensation, and other similar measures. Supposedly these changes should improve the quality of corporate governance, as described earlier.

However, this study finds support for the notion that there is an optimum level which balances the risks and rewards of greater shareholder rights. The following section describes the risks and reward of increasing the level of shareholder rights and summarizes the empirical literature.

\section{A THEORY OF OPTIMUM SHAREHOLDER RIGHTS}

It is generally asserted in the literature that greater shareholder rights ensure a higher value of the firm. There are several reasons for this hypothesis: in the first place, litigation costs may be reduced, since greater transparency of governance processes and financial information, and protection of minority shareholder rights, may result in fewer conflicts. Secondly, agency costs may be minimized, as independent boards can effectively monitor and supervise management. In addition, appropriate incentives may be put in place to enhance managerial performance. Thirdly, greater shareholder-oriented corporate governance may be regarded as a positive signal by investors and analysts. Fourthly, greater transparency may elevate credit ratings, resulting in a lower cost of debt (Ashbaugh-Staife, Collins and LaFonde, 2006). The empirical literature demonstrates that greater shareholder rights generally are associated with higher share prices, higher growth rates, higher profitably and lower volatility in share prices (Bebchuk, Cohen, and Ferrell, 2004; Gompers, Ishii and Metrick, 2003; Deutsche Bank, 2004). Cost of equity capital may also be lower for firms with greater shareholder rights (Gompers, Ishii and Metrick, 2003 and Ashbaugh-Staiffe, Collins and LaFonde, 2004).

On the other hand, it should be emphasized, but it is not so well recognized, that greater shareholder rights in the context of the "Ideal" corporate governance, entail several important costs. These costs include such factors as (1) disclosure to competitors of strategic and tactical information, (2) slower and less efficient decision-making in a competitive environment, (3) a short-run focus on profitability, resulting in reduced capital investment and R\&D expenditures (Lehmann, Warning, and Weigand, 2002), (4) higher career risk requiring higher CEO compensation (Heffes, 2007 and Hermalin and Weisbach, 2007), and (5) higher agency costs for creditors in view of frequent management turnover resulting in lower credit ratings and higher debt costs (Ashbaugh-Staife, Collins and LaFonde, 2006; Weber, 2006), and, finally, (6) higher costs of efforts by the CEO to distort/disguise proprietary and strategic information from the board and the shareholders in order to protect the competitive position of the firm.

A second theory of the firm, in contrast to the "Ideal" of corporate governance implying shareholder ownership and requiring share price maximization, recognizes that the firm is a legal entity and management is expected to be the agent of the firm, not exclusively the agent of the shareholders. Consequently, management has responsibilities to several stakeholders - employees, vendors/customers, and society, in addition to the shareholders. According to this theory, management strives for long-run value creation of the firm, taking into account the interests of all stakeholders (Stout, 2007 and The Economist, 2007). 
A third theory of the firm is based on the failure of the "Ideal" model of corporate governance. In order to reduce the agency costs, incentive compensation schemes have been devised to align the interests of shareholders and the management. Management, whose compensation derives principally from stock option and other bonus plans, may increase the turnover and the volatility of the stock price through share repurchase and other tools of finance, and through excessive risk taking. These strategies may work to the detriment of shareholders and the longrun franchise value of the firm. Speculative efforts by management may dominate over enterprise and innovation (Mitchell 2009 and 2007).

In summary, there are costs and failures associated with greater shareholder rights in the "Ideal" model of corporate governance. In addition, alternative theories of the firm encompass responsibilities for all stakeholders and emphasize the long-run franchise value of the firm. Therefore, this paper asserts that there is an optimum level of shareholder rights which maximizes the value of the firm. The "Ideal" of greater shareholder rights monotonically increasing the value of the firm without limits, is not valid. The concept of an optimum level of shareholder rights are depicted in Figure 1. As shareholder rights increase from some minimum level, involving greater transparency and board independence, the shareholder wealth is initially enhanced. But, beyond some efficient level of shareholder rights, decision processes and judgment may become constrained, inflexible, and costly. Additional liberalization of shareholder rights beyond the optimum may cause the firm to become less competitive and adversely affects the firm's franchise value, as other stakeholders' interests are sacrificed. This study examines the "optimality" of shareholder rights in corporate governance by analyzing the financial performance of firms with varying degrees of shareholder rights.

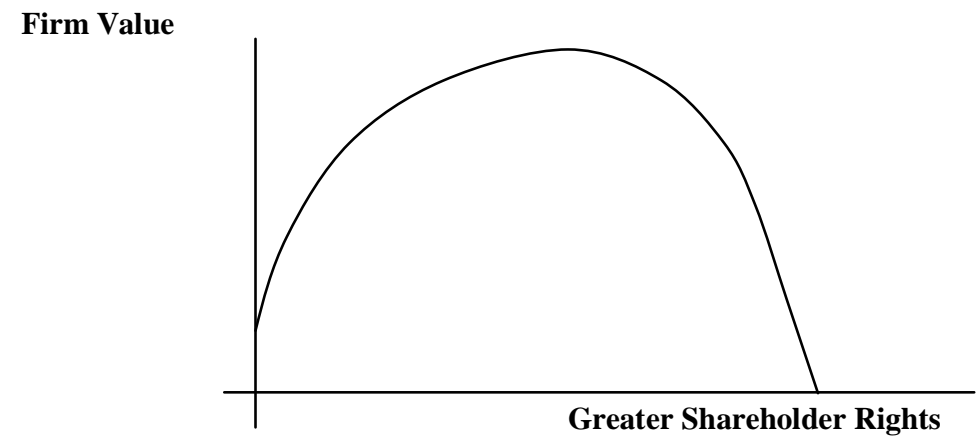

Figure 1: Optimum Shareholder Rights and Firm Value

\section{METHODOLOGY, SAMPLE AND DATA}

This paper measures the level of shareholder rights using the G-Index developed by the Investor Responsibility and Research Center (IRRC) and available at the Wharton Research Data Services (WRDS). The GIndex incorporates all four standards of shareholder rights described above. It consolidates twenty-four provisions which limit shareholder rights, as described in Appendix A, on about 1,800 reporting firms. The G-Index varies from 0 to 24, as each parameter of shareholder rights is given a zero/one score. Zero indicates an absence of that particular limitation on shareholder rights, whereas a "one" indicates the presence of that limiting provision. Therefore, the lower number indicates greater emphasis on shareholder rights, a relative absence of management entrenchment provisions, and greater transparency of information and processes. A higher number indicates greater management entrenchment, less transparency and the existence of more provisions limiting shareholder rights. The G-index is available for the 17-year period 1990 to 2006, with eight census years (1990, 1993, 1995, 1998, 2000, 2002, 2004, and 2006).

Tables 1 and 2 describe the statistical distribution of the population index for various years. It is worth noting in Table 1 that the mean and mode are in the range of 8-10 for all 17 years and the median is 9 for all the sample years. Table 2 highlights the phenomenon that the percentage of firms with G-scores between 8 and 10 is the highest of any category in all the years. Furthermore, an increasing number of firms is clustering around a 
median-level of shareholder rights. Firms are seeking to reduce the risks and costs of both very high and very low levels of shareholder rights.

Table 1: Statistics on G-Index by Year -- IRRC Population (1,800 companies)

\begin{tabular}{|l|c|c|c|c|c|c|c|c|}
\hline & $\mathbf{1 9 9 0}$ & $\mathbf{1 9 9 3}$ & $\mathbf{1 9 9 5}$ & $\mathbf{1 9 9 8}$ & $\mathbf{2 0 0 0}$ & $\mathbf{2 0 0 2}$ & $\mathbf{2 0 0 4}$ & $\mathbf{2 0 0 6}$ \\
\hline Mean & 8.89 & 9.19 & 9.29 & 8.77 & 8.98 & 9.03 & 9.03 & 9.02 \\
\hline Median & 9 & 9 & 9 & 9 & 9 & 9 & 9 & 9 \\
\hline Mode & 10 & 9 & 9 & 10 & 9 & 8 & 8 & 9 \\
\hline Min & 1 & 2 & 2 & 2 & 2 & 1 & 1 & 2 \\
\hline Max & 17 & 17 & 17 & 18 & 19 & 18 & 18 & 18 \\
\hline Std. Dev. & 2.89 & 2.88 & 2.81 & 2.85 & 2.69 & 2.64 & 2.56 & 2.52 \\
\hline
\end{tabular}

Table 2: Distribution of G-Index Frequencies (percentages) - IRRC Population (1,800 companies)

\begin{tabular}{|l|c|c|c|c|c|c|c|c|}
\hline \multicolumn{1}{|c|}{ Categories* } & $\mathbf{1 9 9 0}$ & $\mathbf{1 9 9 3}$ & $\mathbf{1 9 9 5}$ & $\mathbf{1 9 9 8}$ & $\mathbf{2 0 0 0}$ & $\mathbf{2 0 0 2}$ & $\mathbf{2 0 0 4}$ & $\mathbf{2 0 0 6}$ \\
\hline GSR: Class 1-7 & 33.95 & 29.67 & 27.81 & 35.48 & 31.69 & 29.14 & 27.13 & 27.53 \\
\hline MSR: Class 8-10 & 36.06 & 35.95 & 36.83 & 35.68 & 38.95 & 42.29 & 44.38 & 44.57 \\
\hline LSR: Class 11- & 29.99 & 34.38 & 35.36 & 28.84 & 29.36 & 28.56 & 28.49 & 27.90 \\
\hline
\end{tabular}

*GSR denotes Greater Shareholder Rights--it includes companies whose G-Index is less than 8; MSR is the mid-range shareholder rights category and includes companies whose G-Index is 8 through 10; LSR consists of companies with the least shareholder rights and is made up of companies whose G-Index is 11 and above.

The study develops the following categories based on the data in Tables 1 and 2:

- Firms with a G-index score between 1-7 are defined as having the highest level of shareholder rights, denoted as GSR.

- Firms with a G-index score of 11 and above are defined as having the lowest level of shareholder rights, denoted as LSR.

All 1800 IRRC companies were examined since 2000 ( 4 census years for each of the 1,800 companies) and only 8 companies consistently had a G-index score of 7 or below. These are denoted the GSRs. Similarly, only 11 companies consistently had a G-index of 11 and above, and so are designated the LSRs. Table 3 shows the list of companies in each category.

Table 3: List of Firms in the GSR and LSR Categories

\begin{tabular}{|l|l|}
\hline \multicolumn{1}{|c|}{ GSR Firms } & \\
\hline Amazon.Com & Avery Dennison \\
\hline Broadcom & Centex \\
\hline Cisco Sys & Centurytel \\
\hline Loews Corp & Cigna \\
\hline Pepsi Bottling & Exelon \\
\hline Pepsico Inc & Limited Brands \\
\hline Public Storage & Paccar \\
\hline SLM Corp & PPG \\
\hline & Precision Cast \\
\hline & Sovereign \\
\hline & VF Corp \\
\hline
\end{tabular}

\section{PERFORMANCE CRITERIA}

Financial performance of the 19 firms is evaluated on the basis of the variables generally accepted in the evaluation of corporate governance. In particular, they are: (1) sales growth, (2) return on assets (ROA), (3) return on equity (ROE), (4) growth in earnings per share (G-EPS), and (5) price-to-book value (PBV). Data were obtained 
on these variables from the Compustat database for the seven years 2000-06. In order to evaluate the long-term financial performance, the study computed the mean, growth rate, variance and CV for each variable for each company. It also computed the performance of the portfolios of the 8 GSRs and eleven LSRs. Growth coefficients were computed using OLS regression.

\section{RESULTS AND INTERPRETATIONS}

The following section describes the empirical results of the performance variables for GSRs and LSRs. It also sets out the interpretation of the findings in the context of previous empirical studies.

\section{Sales growth}

Table 4 reports the sales growth among the firms according to varying degrees of shareholder rights. Among the GSR companies, 7 of the 8 had statistically significant positive growth rates, and only one had a negative growth rate. Whereas, among the LSR companies, 7 of 11 had significant positive growth rates; one had significant negative growth rate. Three did not show any trend. Thus, a clear majority in both groups demonstrated significant positive growth rates.

It is worth noting that the mean growth rate for both GSR and LSR categories is the same (3\%). This is in complete contrast with the conclusion of Babcheck, et. al. (2004), which predicted higher growth rates for GSR companies.

Table 4 demonstrates that within the GSR group the growth rate varied between positive $11 \%$ and negative $17 \%$, whereas in the LSR category the growth coefficients varied between positive $7 \%$ to negative $2 \%$. The firms in the LSR group attain the same growth rate, on average, as the GSR firms, but exhibited less variance. In summary, GSR is not necessarily correlated with significantly higher sales growth rates and GSRs display more volatility.

Table 4: Sales Growth by Degree of Shareholder Rights: 2000 - 2006*

\begin{tabular}{|l|c|c|c|l|l|c|c|}
\hline \multicolumn{1}{|c|}{ Firms } & $\begin{array}{c}\text { Growth } \\
\text { Rate Coeff }\end{array}$ & T-Stat & R-Sq & \multicolumn{1}{c|}{ Firms } & $\begin{array}{c}\text { Growth } \\
\text { Rate Coeff }\end{array}$ & $\begin{array}{c}\text { T- } \\
\text { Stat }\end{array}$ & $\begin{array}{c}\text { R- } \\
\text { Sq }\end{array}$ \\
\hline Greater Shareholder Rights & & & & Lower Shareholder Rights & & & \\
\hline Amazon.Com & 0.11 & 26.70 & 0.99 & Avery Dennison & 0.03 & 7.91 & 0.93 \\
\hline Broadcom & 0.10 & 7.15 & 0.91 & Centex & 0.07 & 30.20 & 0.99 \\
\hline Cisco System & 0.03 & 2.77 & 0.61 & Century Tel & 0.02 & 4.35 & 0.79 \\
\hline Loews & -0.17 & -2.35 & 0.53 & Cigna & -0.02 & -6.00 & 0.88 \\
\hline Pepsi Bottling & 0.04 & 33.21 & 0.99 & Exelon & 0.03 & 1.82 & 0.40 \\
\hline Pepsico, Inc. & 0.03 & 6.02 & 0.88 & Limited Brands & 0.01 & 0.80 & 0.11 \\
\hline Public Storage & 0.04 & 5.96 & 0.88 & Paccar, Inc. & 0.07 & 4.75 & 0.82 \\
\hline SLM Corp. & 0.05 & 3.08 & 0.65 & PPG Industries & 0.02 & 4.29 & 0.79 \\
\hline Mean growth rate coefficient & 0.03 & & & Precision Cast & 0.05 & 3.66 & 0.73 \\
\hline SD of coefficient & 1.69 & & & Sovereign & 0.04 & 3.49 & 0.71 \\
\hline CV & 56.33 & & & VF Corp. & 0.01 & 1.77 & 0.38 \\
\hline & & & & $\begin{array}{l}\text { Mean growth rate } \\
\text { coefficient }\end{array}$ & 0.03 & \\
\hline & & & & SD of coefficient & 0.02 & & \\
\hline & & & & CV & 0.67 & & \\
\hline
\end{tabular}

*Growth rate coefficient has been calculated by regressing the log of sales against time. The mean, standard deviation and CV have been calculated using only the statistically significant growth coefficients 
Table 5: Return on Assets (ROA) of Firms by Degree of Shareholder Rights

\begin{tabular}{|c|c|c|c|c|c|c|c|c|c|c|}
\hline Greater Shareholder Rights & 2000 & 2001 & 2002 & 2003 & 2004 & 2005 & 2006 & Mean & SD & CV \\
\hline Amazon.Com & -66.1 & -34 & -7.53 & 1.63 & 18.11 & 9.01 & 4.36 & -10.65 & 29.49 & -2.77 \\
\hline Broadcom & -14.7 & -75.68 & -100.92 & -47.57 & 7.58 & 9.78 & 7.77 & -30.53 & 44.87 & -1.47 \\
\hline Cisco Sys & 8.12 & -2.88 & 5.01 & 9.64 & 13.96 & 16.94 & 12.88 & 9.10 & 6.59 & 0.72 \\
\hline Loews Corp & 2.65 & -0.71 & 1.39 & -0.86 & 1.68 & 1.69 & 3.27 & 1.30 & 1.57 & 1.20 \\
\hline Pepsi Bottling & 2.96 & 3.88 & 4.27 & 3.66 & 4.23 & 4.04 & 4.38 & 3.92 & 0.49 & 0.12 \\
\hline Pepsico Inc & 11.9 & 12.25 & 14.1 & 14.08 & 14.9 & 12.85 & 18.84 & 14.13 & 2.34 & 0.17 \\
\hline Public Storage & 4.12 & 4.04 & 3.3 & 3.22 & 3.45 & 4.47 & 0.4 & 3.29 & 1.36 & 0.41 \\
\hline SLM Corp & 0.93 & 0.7 & 1.47 & 2.16 & 2.26 & 1.37 & 0.97 & 1.41 & 0.61 & 0.43 \\
\hline Mean & -6.27 & -11.55 & -9.86 & -1.76 & 8.27 & 7.52 & 6.61 & \multicolumn{2}{|c|}{ Mean: 56 obs. } & -1.01 \\
\hline SD & 25.39 & 29.29 & 37.26 & 19.13 & 6.47 & 5.58 & 6.34 & \multicolumn{2}{|c|}{ SD: 56 obs. } & 22.19 \\
\hline $\mathbf{C V}$ & -4.05 & -2.54 & -3.78 & -10.90 & 0.78 & 0.74 & 0.96 & \multicolumn{2}{|c|}{ CV: 56 obs. } & -22.07 \\
\hline \multicolumn{11}{|l|}{ Lower Shareholder Rights } \\
\hline Avery Dennison & 10.5 & 8.63 & 7.04 & 5.91 & 6.36 & 6.94 & 8.21 & 7.66 & 1.58 & 0.21 \\
\hline Centex & 6.45 & 4.24 & 4.25 & 4.79 & 4.84 & 5.05 & 5.72 & 5.05 & 0.80 & 0.16 \\
\hline Centurytel & 3.61 & 5.42 & 2.44 & 4.36 & 4.32 & 4.3 & 4.97 & 4.20 & 0.96 & 0.23 \\
\hline Cigna Corp & 1.04 & 1.08 & -0.45 & 0.66 & 1.95 & 2.84 & 2.73 & 1.41 & 1.18 & 0.84 \\
\hline Exelon & 1.64 & 4.07 & 4.46 & 1.89 & 4.3 & 2.24 & 3.59 & 3.17 & 1.21 & 0.38 \\
\hline Limited Brands & 10.47 & 11 & 6.85 & 9.11 & 11.58 & 10.5 & 9.52 & 9.86 & 1.57 & 0.16 \\
\hline Paccar & 5.34 & 2.19 & 4.28 & 5.3 & 7.42 & 8.26 & 9.29 & 6.01 & 2.46 & 0.41 \\
\hline PPG Industries & 6.8 & 4.58 & -0.76 & 5.94 & 7.65 & 6.87 & 7.1 & 5.45 & 2.91 & 0.53 \\
\hline Precision Cast & 3.53 & 4.85 & 1.65 & 6.46 & 3.61 & 6.61 & 9.31 & 5.15 & 2.53 & 0.49 \\
\hline Sovereign & -0.12 & 0.35 & 0.87 & 0.92 & 0.83 & 1.06 & 0.14 & 0.58 & 0.45 & 0.78 \\
\hline VF Corp & 6.03 & 3.22 & 10.16 & 9.32 & 9.45 & 10 & 9.78 & 8.28 & 2.64 & 0.32 \\
\hline Mean & 4.34 & 3.92 & 3.38 & 4.95 & 5.85 & 6.05 & 6.43 & \multicolumn{2}{|c|}{ Mean: 77 obs. } & 5.17 \\
\hline SD & 3.51 & 3.29 & 3.80 & 3.46 & 3.77 & 3.61 & 3.76 & \multicolumn{2}{|c|}{ SD: 77 obs. } & 3.20 \\
\hline $\mathrm{CV}$ & 0.81 & 0.84 & 1.12 & 0.70 & 0.64 & 0.60 & 0.60 & \multicolumn{2}{|c|}{ CV: 77 obs. } & 0.62 \\
\hline
\end{tabular}

\section{Return on Assets (ROA)}

Table 5 reports ROA results for each firm and for each year in the sample period. Out of the 8 GSR firms, six exhibited positive average ROAs over the sample period, whereas two exhibited very large, negative ROAs. On the other hand, all 11 LSRs reported positive ROAs. Furthermore, the LSRs, with 77 observations, exhibited only three negative returns. Out of 56 observations for GSRs there were nine cells with negative returns. Thus, GSRs displayed greater variability in their performance over the sample period.

The mean return for the portfolio of the GSR firms was negative for 4 out of 7 years, whereas the portfolio of LSR firms reported positive returns for all 7 years. A portfolio of GSRs held over 2000-2006 generated a mean return of negative 1.01 percent with standard deviation of 22.19. Whereas, a LSR portfolio generated a mean return of positive 5.17 percent with volatility of only 3.2 .

In summary, the LSR's portfolio outperformed the GSR's portfolio with less risk. These findings are contrary to the results described by Bebchuk, et. al. (2004), and Gompers, et. al. (2003), which assert that greater shareholders rights generate higher profitability and lower volatility.

\section{Return on Equity (ROE)}

Table 6 reports the ROE performance of the firms. Seven out of eight GSRs exhibited positive mean ROEs, whereas all LSR firms achieved positive mean ROEs. For 56 observations amongst GSRs, 7 cells had negative ROEs; whereas, among LSRs, only 3 out of 77 cells are negative.

The portfolio of GSRs generated a mean ROE of $13.69 \%$ with standard deviation of 35.04 ; whereas, an LSR portfolio generated a mean ROE of $16.1 \%$ with volatility of 8.10 . The portfolio of LSRs demonstrated positive returns for each of the 7 years, whereas the GSR's portfolio demonstrated positive returns for 5 out of 7 years. These results are similar to those for the ROAs reported earlier. 
In summary, LSRs have higher ROEs with lower business and financial risks, compared to the GSRs. This stands in contrast to the previous literature.

Table 6: Return on Equity (ROE) of Firms by Degree of Shareholder Rights

\begin{tabular}{|c|c|c|c|c|c|c|c|c|c|c|}
\hline Greater Shareholder Rights & 2000 & 2001 & 2002 & 2003 & 2004 & 2005 & 2006 & Mean & SD & $\mathbf{C V}$ \\
\hline Amazon.Com & 0.00 & 0.00 & 0.00 & 0.00 & 0.00 & 135.37 & 44.08 & 25.64 & 51.10 & 1.99 \\
\hline Broadcom & -15.37 & -85.49 & -136.00 & -64.43 & 9.25 & 11.69 & 9.04 & -38.76 & 57.71 & -1.49 \\
\hline Cisco Sys & 10.07 & -3.74 & 6.61 & 12.77 & 19.24 & 24.77 & 23.34 & 13.29 & 10.11 & 0.76 \\
\hline Loews Corp & 16.77 & -5.55 & 8.75 & -6.03 & 10.16 & 9.11 & 15.25 & 6.92 & 9.20 & 1.33 \\
\hline Pepsi Bottling & 13.91 & 19.05 & 23.47 & 22.44 & 23.45 & 22.81 & 25.05 & 21.45 & 3.80 & 0.18 \\
\hline Pepsico Inc & 30.11 & 30.72 & 35.59 & 29.97 & 30.73 & 28.46 & 36.51 & 31.73 & 3.06 & 0.10 \\
\hline Public Storage & 7.24 & 7.88 & 6.82 & 6.80 & 7.70 & 10.70 & 0.84 & 6.85 & 2.97 & 0.43 \\
\hline SLM Corp & 36.27 & 24.71 & 42.58 & 56.47 & 64.75 & 42.16 & 29.55 & 42.36 & 14.22 & 0.34 \\
\hline Mean & 12.38 & -1.55 & -1.52 & 7.25 & 20.66 & 35.63 & 22.96 & \multicolumn{2}{|c|}{ Mean: 56 obs. } & 13.69 \\
\hline SD & 16.31 & 36.48 & 56.41 & 34.98 & 20.32 & 41.79 & 14.24 & \multicolumn{2}{|c|}{ SD: 56 obs. } & 35.04 \\
\hline $\mathbf{C V}$ & 1.32 & -23.49 & -37.05 & 4.83 & 0.98 & 1.17 & 0.62 & \multicolumn{2}{|c|}{ CV: 56 obs. } & 2.56 \\
\hline \multicolumn{11}{|l|}{ Lower Shareholder Rights } \\
\hline Avery Dennison & 34.24 & 26.19 & 24.35 & 18.41 & 18.06 & 19.30 & 20.98 & 23.08 & 5.80 & 0.25 \\
\hline Centex & 18.12 & 16.45 & 18.06 & 20.92 & 25.48 & 23.63 & 24.36 & 21.00 & 3.56 & 0.17 \\
\hline Centurytel & 11.42 & 14.71 & 6.15 & 9.92 & 9.90 & 9.26 & 11.61 & 10.42 & 2.61 & 0.25 \\
\hline Cigna & 18.23 & 19.57 & -10.27 & 13.21 & 30.31 & 23.81 & 26.77 & 17.38 & 13.44 & 0.77 \\
\hline Exelon & 7.85 & 17.48 & 21.57 & 9.33 & 19.54 & 10.42 & 15.94 & 14.59 & 5.38 & 0.37 \\
\hline Limited Brands & 18.47 & 18.91 & 10.21 & 13.62 & 30.19 & 26.95 & 22.84 & 20.17 & 7.07 & 0.35 \\
\hline Inc & 19.64 & 7.71 & 14.30 & 16.22 & 24.10 & 29.05 & 33.57 & 20.66 & 8.92 & 0.43 \\
\hline PPG & 20.02 & 12.57 & -2.79 & 17.18 & 19.12 & 19.52 & 21.99 & 15.37 & 8.54 & 0.56 \\
\hline Precision Cast & 11.02 & 13.85 & 4.46 & 15.01 & 7.90 & 13.45 & 16.31 & 11.71 & 4.23 & 0.36 \\
\hline Sovereign & -2.11 & 5.60 & 12.37 & 12.33 & 9.09 & 11.64 & 1.53 & 7.21 & 5.74 & 0.80 \\
\hline VF Corp & 12.00 & 6.26 & 21.47 & 20.28 & 18.82 & 18.41 & 16.37 & 16.23 & 5.36 & 0.33 \\
\hline Mean & 13.14 & 12.74 & 8.92 & 14.65 & 19.88 & 19.16 & 19.42 & \multicolumn{2}{|c|}{ Mean: 77 obs. } & 16.17 \\
\hline SD & 7.66 & 5.69 & 11.25 & 3.33 & 8.41 & 7.03 & 9.44 & \multicolumn{2}{|c|}{ SD: 77 obs. } & 8.10 \\
\hline $\mathrm{CV}$ & 0.58 & 0.45 & 1.26 & 0.23 & 0.42 & 0.37 & 0.49 & \multicolumn{2}{|c|}{ CV: 77 obs. } & 0.50 \\
\hline
\end{tabular}

Table 7: Growth of Earnings per Share (G-EPS) by Degree of Shareholder Rights

\begin{tabular}{|l|c|c|c|l|c|c|c|c|}
\hline $\begin{array}{c}\text { Greater Shareholder } \\
\text { Rights }\end{array}$ & Growth Coeff & T-Stat & R-Sqd & $\begin{array}{c}\text { Lower Shareholder } \\
\text { Rights }\end{array}$ & Growth Coeff & T-Stat & R-Sqd \\
\hline Amazon.Com & 0.713 & 3.45 & 0.7 & Avery Dennison & 0.11 & 1.78 & 0.39 \\
\hline Broadcom & 1.078 & 2.43 & 0.54 & Centex & 0.32 & 0.47 & 0.04 \\
\hline Cisco Sys & 0.145 & 3.42 & 0.7 & Centurytel & 0.21 & 2.54 & 0.56 \\
\hline Loews Corp & 0.27 & 0.71 & 0.09 & Cigna & 0.40 & 1.41 & 0.28 \\
\hline Pepsi Bottling & 0.224 & 11.16 & 0.96 & Exelon & 0.05 & 0.41 & 0.03 \\
\hline Pepsico Inc & 0.29 & 6.21 & 0.89 & Limited Brands & 0.127 & 5.22 & 0.85 \\
\hline Public Storage & -0.08 & -0.9 & 0.14 & Paccar & 0.53 & 4.98 & 0.83 \\
\hline SLM Corp & 0.463 & 2.62 & 0.56 & PPG & 0.32 & 1.07 & 0.19 \\
\hline Mean & $\mathbf{0 . 4 9 *}$ & & & Precision Cast & 0.52 & 3.49 & 0.71 \\
\hline SD & $\mathbf{0 . 3 5 *}$ & & & Sovereign & 0.14 & 1.11 & 0.2 \\
\hline CV & $\mathbf{0 . 7 3}$ & & & VF Corp & 0.554 & 4.69 & 0.81 \\
\hline & & & Mean & $\mathbf{0 . 3 9 *}$ & & \\
\hline & & & & SD & $\mathbf{0 . 2 0}^{*}$ & & \\
\hline
\end{tabular}

\footnotetext{
*Mean, standard deviation and CV have been calculated for the statistically significant coefficients.
} 


\section{Growth Rates in Earnings per Share (G-EPS)}

EPS growth rates are reported in Table 7. Amongst the GSRs, 6 out of 8 ( 75 percent) showed statistically significant positive growth rates. Amongst the LSR firms only 5 of the 11 (45 percent) showed statistically significant positive growth rates. The mean growth rate amongst the GSRs was 49 percent; whereas, for the LSRs it was 39 percent. The GSR's portfolio exhibited more volatile growth rates with CV of $73 \%$; whereas, for the LSR's firms CV was 52\%. To summarize, the GSRs exhibited higher EPS growth rates on average, but with higher volatility.

Table 8: Price to Book Value Ratio (PBV) by Degree of Shareholder Rights

\begin{tabular}{|c|c|c|c|c|c|c|c|c|c|c|}
\hline \multirow{2}{*}{$\begin{array}{c}\text { Greater } \\
\text { Shareholder Rights }\end{array}$} & \multicolumn{10}{|c|}{\begin{tabular}{|l|l|l|} 
& &
\end{tabular}} \\
\hline & 2000 & 2001 & 2002 & 2003 & 2004 & 2005 & 2006 & Mean & SD & $\mathrm{CV}$ \\
\hline \multicolumn{11}{|l|}{ Amazon.Com* } \\
\hline Broadcom & 5.56 & 2.33 & 0.96 & 5.98 & 3.93 & 4.83 & 3.75 & 3.90 & 1.78 & 0.46 \\
\hline Cisco Sys & 22.95 & 5.39 & 3.40 & 4.95 & 5.44 & 5.15 & 4.43 & 7.39 & 6.90 & 0.93 \\
\hline Loews Corp & 0.97 & 1.09 & 0.74 & 0.88 & 1.14 & 1.37 & 1.42 & 1.09 & 0.25 & 0.23 \\
\hline Pepsi Bottling & 3.55 & 3.85 & 3.69 & 3.45 & 3.63 & 3.30 & 3.16 & 3.52 & 0.24 & 0.07 \\
\hline Pepsico Inc & 10.38 & 8.75 & 7.66 & 7.33 & 6.86 & 6.93 & 6.39 & 7.76 & 1.38 & 0.18 \\
\hline Public Storage & 1.21 & 1.72 & 1.69 & 2.44 & 3.20 & 3.90 & 3.07 & 2.46 & 0.98 & 0.40 \\
\hline SLM Corp & 9.53 & 9.68 & 9.61 & 6.85 & 8.39 & 7.06 & 5.06 & 8.03 & 1.77 & 0.22 \\
\hline Mean & 7.74 & 4.69 & 3.96 & 4.55 & 4.66 & 4.65 & 3.90 & \multicolumn{2}{|c|}{ Mean: 49obs. } & 4.88 \\
\hline SD & 7.66 & 3.41 & 3.43 & 2.39 & 2.43 & 2.02 & 1.59 & \multicolumn{2}{|c|}{ SD: 49obs. } & 3.75 \\
\hline $\mathbf{C V}$ & 0.99 & 0.73 & 0.87 & 0.53 & 0.52 & 0.43 & 0.41 & \multicolumn{2}{|c|}{ CV: 49obs. } & 0.77 \\
\hline \multirow{2}{*}{\multicolumn{11}{|c|}{$\begin{array}{c}\text { Lower } \\
\text { Shareholder Rights }\end{array}$}} \\
\hline & & & & & & & & & & \\
\hline Avery Dennison & 7.71 & 6.68 & 6.57 & 4.91 & 4.67 & 3.81 & 4.27 & 5.52 & 1.46 & 0.27 \\
\hline Centex & 1.54 & 1.60 & 1.37 & 2.14 & 1.89 & 1.60 & 1.02 & 1.59 & 0.36 & 0.23 \\
\hline Centurytel & 2.54 & 2.03 & 1.37 & 1.40 & 1.40 & 1.22 & 1.52 & 1.64 & 0.47 & 0.29 \\
\hline Cigna & 3.78 & 2.52 & 1.29 & 1.91 & 2.35 & 2.48 & 3.17 & 2.50 & 0.81 & 0.32 \\
\hline Exelon & 12.95 & 1.98 & 2.00 & 2.61 & 3.06 & 3.49 & 4.28 & 4.34 & 3.88 & 0.90 \\
\hline Limited Brands & 4.21 & 3.28 & 1.46 & 1.92 & 2.16 & 4.50 & 4.38 & 3.13 & 1.28 & 0.41 \\
\hline Paccar & 1.67 & 2.24 & 2.10 & 3.21 & 3.76 & 2.91 & 3.42 & 2.76 & 0.77 & 0.28 \\
\hline PPG & 2.49 & 2.81 & 3.06 & 4.31 & 3.60 & 2.92 & 3.05 & 3.18 & 0.60 & 0.19 \\
\hline Precision Cast & 1.95 & 2.06 & 1.16 & 1.71 & 2.97 & 3.95 & 5.33 & 2.73 & 1.47 & 0.54 \\
\hline Sovereign & 0.97 & 1.41 & 1.35 & 2.19 & 1.62 & 1.36 & 1.41 & 1.47 & 0.37 & 0.25 \\
\hline VF Corp & 1.83 & 1.90 & 2.30 & 2.52 & 2.60 & 2.25 & 2.94 & 2.34 & 0.39 & 0.17 \\
\hline Mean & 3.73 & 2.27 & 1.84 & 2.55 & 2.76 & 2.98 & 3.50 & Mean: & 7obs. & 2.84 \\
\hline SD & 3.88 & 0.58 & 0.65 & 0.86 & 0.73 & 0.99 & 1.18 & SD: 77 & & 1.79 \\
\hline $\mathrm{CV}$ & 1.04 & 0.26 & 0.35 & 0.34 & 0.26 & 0.33 & 0.34 & CV: 77 & & 0.63 \\
\hline
\end{tabular}

*Amazon.com is not being used in this calculation as it had negative equity for several of the years.

\section{Price to Book Value (PBV)}

Table 8 reports the results for PBV. GSRs demonstrated a mean PBV of 4.88x, higher than the PBV for LSR firms of 2.84x. The volatility for GSRs is higher, with CV of 0.77 , compared to the CV of 0.63 for LSRs.

In about 8 percent of the observations, the share price of the GSRs is less than the book value. In contrast, only one LSR observation (1.3\%) is less than 1. The number of observations with PBV between 1 and 2 is 14.3 percent for GSRs; whereas, for LSRs it is 35 percent. The portfolio of GSRs is more volatile with CV higher in 6 of the 7 years.

In summary, the PBV is higher but more volatile for GSRs. This is in contrast to the previous literature: Ashbaugh-Staiffe, et. al. (2004). 


\section{SUMMARY AND CONCLUSION}

The previous corporate governance literature states that greater shareholder rights will ensure higher stock prices, higher sales growth rates, higher profitability and lower cost of equity capital. This assertion is based upon the "ideal" concept of firm ownership by the shareholders in which the management is the exclusive agent of the shareholders. This "ideal" ignores alternative views which emphasize the firm's responsibility to all stakeholders. In addition, this view does not consider the potential for failure of incentive compensation schemes for management. The present study argues that there is an optimum level of shareholder rights, based upon considerations of various costs and risks of increasing shareholder rights. With increasing shareholder rights beyond some optimum level, decision processes and judgment may become cumbersome and inflexible. Furthermore, liberalization of shareholder rights beyond the optimum may distort managerial enterprise and innovation. It may also adversely affect the franchise value as other stakeholder interests get sacrificed.

This paper finds that the median level of shareholder rights has not changed in the last 17 years, and furthermore, firms have a tendency to converge toward the median level. The study evaluates the financial performance of firms with varying degrees of shareholder rights. It finds that firms with greater shareholder rights show higher growth rates in earnings per share, higher price to book value ratio, and equal sales growth rates, compared to firms with lower shareholder rights. However, these results for the GSRs are associated with higher volatility in these variables. It should be emphasized that firms with lower shareholder rights achieved higher profitability (ROA and ROE) with lower volatility. In summary, firms with lower shareholder rights demonstrated greater stability without any diminution in financial performance. These results contrast with the findings of the previous literature.

\section{AUTHOR INFORMATION}

Lal C. Chugh is Professor of Finance at the University of Massachusetts Boston. He received the PhD from Harvard University. Dr. Chugh has published extensively in the areas of international finance, and financial markets and institutions in both academic and practitioner journals, such as The Financial Analysts Journal, Journal of Asset Management, International Review of Business Research Papers, The Financial Executive, Journal of Economic Studies, Journal of Business Finance and Accounting, and others. Dr. Chugh's current research activities include analyzing corporate governance in various countries and the impact of globalization.

Joseph W. Meador is Professor of Finance at Northeastern University in Boston. He received the PhD from the Wharton School at the University of Pennsylvania. He has published extensively in areas of financial performance and corporate governance in such journals as the Journal of Risk and Insurance, the Financial Analysts Journal, Journal of Business and Economics Research, Financial Executive, the CPCU Journal, Journal of the Academy of Finance, and others. Dr. Meador's current research deals with corporate governance, mergers and acquisitions and financial performance.

Matthew W. Meador is an MBA candidate at the University of Michigan. He received the B.ChE. (magna cum laude) from Northeastern University. He has several years' experience in the bio-medical industry, conducting quality control, process engineering and research experiments, principally in the areas of medical device development and production.

\section{REFERENCES}

1. Ashbaugh-Staife, Hollis and Collins, Daniel W., and LaFond, Ryan. The Effects of Corporate Governance on Firms' Credit Ratings, Journal of Accounting and Economics, Vol. 42 (1-2), October 2006, 2003-2043.

2. Ashbaugh-Staife, Hollis and Collins, Daniel W., and LaFond, Ryan. "Corporate Governance and the Cost of Equity Capital", December 2004, SSRN.com

3. Bebchuk, Lucian A. Letting Shareholders Set the Rules, Harvard Law Review, Vol. 119, 2006, pp. 17841813.

4. Bebchuk, Lucian A., Cohen, Alma, and Ferrell, Allen. Harvard Law School, John M. Olin Center, Discussion Paper Number 491, 2004. 
5. Chugh, Lal C. and Meador, Joseph W. "An Analysis of the Levels and Patterns of Shareholder Rights: 1990 - 2006." Journal of Business and Economics Research, vol. 6 no. 5, May 2008, pp. 77-86

6. Deutsche Bank, AG. Beyond the Numbers: Corporate Governance: Implications for Investors, 2004.

7. Economist The, "Keeping Shareholders in their Place," October 13, 2007, pp. 69-70

8. Gompers, Paul A., Ishii, Joy L., Metrick, Andrew. Corporate Governance and Equity Prices, Quarterly Journal of Economics, 118 (1), February 2003, pp. 107-155.

9. Heffes, Ellen M. "Have the New Rules Improved Boards?" Financial Executive, May 2007, pp. 30-35.

10. Hermalin, Benjamin E., Weisbach, Michael S. Transparency and Corporate Governance. NBER Working Paper, 2007.

11. Lehmann, Arik E., Warning, Susanne, and Weigand, Jurgen. Efficient Governance Structures, Corporate Investment and Profitability. GEABA Discussion Paper Number 02-07.

12. Mitchell, Lawrence E. "Protect Industry from Predatory Speculators," Financial Times, July 9, 2009, p. 9.

13. Mitchell, Lawrence E. "The Speculation Economy: How Finance Triumphed over Industry." BerrettKoehler Publishers, Inc., 2007.

14. Stout, Lynn A. “Corporations Shouldn’t Be Democracies,” Wall Street Journal, September 27, 2007, p. A17.

15. Weber, Joseph. Discussion of the Effects of Corporate Governance on Firms' Credit Ratings, Journal of Accounting and Economics, Vol. 42 (1-2), October 2006, pp. 245-254. 


\section{APPENDIX A: 24 COMPONENTS OF THE G-INDEX}

\begin{tabular}{|c|c|}
\hline 1. Antigreenmail & $\begin{array}{l}\text { Prohibits Large shareholder from not seeking control of a company in exchange for right } \\
\text { to sell stock back at a premium, unless all shareholders offered same opportunity. }\end{array}$ \\
\hline $\begin{array}{l}\text { 2. Directors Indemnification } \\
\text { Contract }\end{array}$ & $\begin{array}{l}\text { Firm is contractually obligated to pay legal expenses and judgments for suits alleging } \\
\text { misconduct. }\end{array}$ \\
\hline 3. No-Secret Ballot & Allows management to examine individual proxy cards. \\
\hline 4. $\quad$ Blank Check & Allows Board broad latitude in determining shareholder rights. \\
\hline 5. $\quad$ Fair Price & Limits the rights of shareholders to tender shares. \\
\hline 6. Pension Parachutes & Acquirer cannot use surplus pension funds to finance acquisition. \\
\hline 7. Business Combination Law & Imposes moratorium on M\&A by a large shareholder \\
\hline 8. Golden Parachutes & Lavish severance agreements for senior executives following change in control \\
\hline 9. Poison Pill & Target firm shareholders have right to buy additional shares at a steep discount. \\
\hline 10. Cash-Out Law & Forces acquirer to pay highest recent price to all shareholders. \\
\hline 11. Limit to amend by-Laws & Eliminates or limits the right of shareholders or the Board to amend the by-laws. \\
\hline 12. Severance Agreements & Assures officers of their positions/compensation without reference to changes in control. \\
\hline 13. Compensation Plans & Allows cash out of options or accelerated bonuses in the event of changes in control. \\
\hline 14. Limit to Amend Charter & Eliminates or limits the right of shareholders or the Board to amend the charter. \\
\hline 15. Silver Parachutes & $\begin{array}{l}\text { Similar to golden parachutes, but in this case a large number of employees is eligible in } \\
\text { the event of change in control. }\end{array}$ \\
\hline $\begin{array}{l}\text { 16. Director Indemnification } \\
\text { contracts }\end{array}$ & $\begin{array}{l}\text { Charter and by-laws obligate firm to pay legal expenses and judgments for suits alleging } \\
\text { misconduct against officers and directors. }\end{array}$ \\
\hline 17. Limits to Special Meeting & $\begin{array}{l}\text { Eliminates or limits ability of shareholders to call a special meeting of the corporate } \\
\text { shareholders. }\end{array}$ \\
\hline 18. Director Liability & Eliminates or limits Directors personal liability for certain acts. \\
\hline 19. Limits Written Consent & $\begin{array}{l}\text { Limit ability of management and Board to negotiate M\&A to regularly scheduled } \\
\text { meeting. }\end{array}$ \\
\hline 20. Staggered Board & Only part of the Board is elected each year. \\
\hline 21. Unequal Voting & Long-term shareholders are given more vote than recent buyers. \\
\hline 22. Supermajority & Supermajority of voting shareholders required for M\&A. \\
\hline 23. Directors Duties & Allows Board to consider other constituencies to reject takeover. \\
\hline 24. No-Cumulative Voting & $\begin{array}{l}\text { Limits rights of dissident shareholders. Reduces number of independent/dissident } \\
\text { directors. }\end{array}$ \\
\hline
\end{tabular}


NOTES 